\title{
Meningkatkan Kompetensi Guru SD Negeri 29 Ampenan Semester Dua Tahun Pelajaran 2018/2019 Dalam Penulisan Soal Pilihan Ganda Yang Berkriteria Untuk Berfikir Tingkat Tinggi Melalui Pendampingan Berbasis KKG
}

\author{
Hj. Sapirah \\ Kepala SD Negeri 29 Ampenan.
}

\begin{abstract}
Abstrak; Tujuan penelitian ini adalah untuk mengetahui sejauh mana efektifitas pelaksanaan Pendampingan klasikal dan individual dalam upaya meningkatkan kompetensi guru kelas tinggi di SD Negeri 29 Ampenan dalam penulisan soal pilihan ganda yang baik dan benar. Berdasarkan beberapa bagian pustaka, maka hipotesis tindakan dalam penelitian ini adalah: pelaksanaan pendampingan klasikal dan individu dapat meningkatkan kompetensi guru kelas tinggi di SD Negeri 29 Ampenan dalam penulisan soal pilihan ganda yang baik dan benar. Penelitian ini dilaksanakan sebanyak dua siklus, masing-masing siklus satu kali pertemuan melalui tahapan: perencanaan, pelaksanaan, pengamatan dan refleksi. Hasil penelitia pada siklus dua pengamatan kegiatan kepala sekolah diperoleh skor rata-rata 4,50, pengamatan kegiatan guru memperoleh skor rata-rata 4,37 sedangkan hasil kerja individual dalam penulisan soal pilihan ganda memperoleh skor rata-rata 92,24. Indikator keberhasilan untuk pengamatan/observasi $\geq 4,00$ dan nilai kerja individual $\geq 85,00$. Indicator keberhasilan telah terpenuhi. Penelitian Tindakan Sekolah (PTS) dihentikan pada siklus kedua dengan hasil sangat memuaskan. Beberapa kendala/hambatan selama penelitian dapat diatasi dengan baik, sehingga dalam pencapaian indicator dengan cepat terpenuhi. Disarankan kepada kepala sekolah yang lain untuk mengadakan penelitian sejenis dalam upaya meningkatkan kompetensi kepala sekolah yang professional.
\end{abstract}

Kata Kunci : Kompetensi Guru, Pendampingan Klasikal dan individual.

\section{PENDAHULUAN}

Kaidah-kaiaadah penulisan soal bentuk pilihan ganda meliputi 3 (tiga) kriteria yaitu; 1) materi ( soal harus sesuai dengan indikator, pilihan jawaban harus homogen dan logis ditinjau dari segi materi, dan setiap soal harus mempunyai satu jawaban yang benar atau paling benar), 2) konstruksi; a) pokok soal harus dirumuskan secara jelas dan tegas, (b) rumusan pokok soal menggunakan stimulus dalam bentuk ilustrasi/kasus/ peristiwa/ gambar/ tabel/ diagram dan sejenisnya, (c) pilihan jawaban harus merupakan pernyataan yang diperlukan saja, (d) pokok soal jangan memberi petunjuk kearah jawaban yang benar, (e) pokok soal jangan mengandung pernyataan yang bersifat negatif ganda, (f) panjang rumusan pilihan jawaban harus relatif sama, (g) pilihan jawaban jangan mengandung pernyataan "semua pilihan jawaban di atas salah" atau "semua pilihan jawaban diatas benar", (h) pilihan jawaban yang berbentuk angka/waktu harus disusun berdasarkan urutan besar kecilnya nilai angka tersebut atau secara kronologis, (i) gambar, grafik, tabel, diagram, dan sejenisnya yang terdapat pada soal harus jelas dan berfungsi, (j) soal jangan bergantung pada jawaban soal sebelumnya atau lainnya, 3) bahasa; (a) setiap soal harus menggunakan bahasa yang sesuai dengan kaidah bahasa Indonesia, (b) jangan menggunakan bahasa yang berlaku setempat, dan (c) pilihan jawaban jangan mengulang kata/frasse yang sama yang bukan merupakan satu kesatuan pengertian. (sumber; paduan bagaimana pendidik dapat menulis soal yang berkriteria untuk berfikir tingkat tinggi, 2016).

Kondisi nyata yang terjadi di SD Negeri 29 Ampenan menunjukkan bahwa kebanyakan guru yang mengajar di kelas, untuk mengetahui kualitas hasil belajar bagi peserta didiknya cenderung menggunakan soal bentuk uraian (essay) terstruktur dan atau dalam bentuk uraian tidak terstruktur. Hal itu dilakukan oleh guru dengan alasan bahwa membuat soal bentuk uraian lebih cepat dan lebih mudah bila dibandingkan dengan menyusun soal bentuk pilihan ganda. Soal dalam bentuk pilihan ganda cara membuatnya 
sulit dan sangat rumit, tetapi bagi peserta didik sangat cepat menjawabnya walaupun hasilnya masih belum sesuai dengan kunci jawaban yang diharapkan. Guru berpendapat membuat soal pilihan ganda membutuhkan waktu yang cukup lama, tetapi peserta didik mengerjakan cepat selesai dalam waktu yang relatif singkat, sedangkan membuat soal bentuk uraian sangat cepat selesai tetapi peserta didik mengerjakannya membutuhkan waktu yang relatif lama.

Adapun faktor penyebab rendahnya kompetensi guru kelas dalam penyusunan soal berbentuk pilihan ganda antara lain: 1) belum pernah mengikuti pendidikan dan pelatihan (DIKLAT) yang materinya khusus tata cara penyusunan soal bentuk pilihan ganda yang baik dan benar, 2) kepala sekolah belum pernah mengadakan bimbingan khusus tentang tata cara penyusunan sola pilihan ganda yang sesuai dengan kaidah penyusunan soal yang baik dan benar, 3) kegiatan KKG tidak pernah membahas tentang sistem penilaian yang terfokus pada tata cara penyusunan soal pilihan ganda sesuai dengan kaidah yang baik dan benar, 4) guru berpendapat menyusun soal bentuk uraian lebih mudah dan cepat selesai bila dibandingkan dengan membuat soal bentuk pilihan ganda.

Banyak solusi yang bisa dilakukan oleh peneliti dalam upaya meningkatkan kompetensi guru kelas dalam penyusunan soal pilihan ganda yang baik dan benar sesuai dengan kaidah yang berlaku. Salah satu solusi solusi yang bisa dilakukan oleh peneliti yaitu dengan mengadakan pendampingan berbasis KKG bagi guru kelas dalam penyusunan soal pilihan ganda yang baik dan benar sesuai dengan kaidah yang berlaku. Ada beberapa keunggulan pelaksanaan pendampingan berbasis KKG yaitu : 1) permasalahan yang rumit bisa menjadi sederhana, 2) pekerjaan yang sulit bisa menjadi mudah, 3) menjalin tali persaudaraan, persahabatan, dan silaturrahmi antara sesama guru dan dengan kepala SD Negeri 29 Ampenan, dan 4) proses pembelajaran menjadi bermakna sebagai dampak positif dari tersusunnya soal bentuk pilihan ganda sesuai dengan kaidah.
Untuk menjawab wacana diatas maka dipandang perlu diadakan Penelitian Tindakan Sekolah (PTS) bagi kepala SD Negeri 29 Ampenan dengan judul "Meningkatkan Kompetensi Guru SD Negeri 29 Ampenan Semester Dua Tahun Pelajaran 2018/2019 Dalam Penulisan Soal Pilihan Ganda Yang Berkriteria Untuk Berfikir Tingkat Tinggi Melalui Pendampingan Berbasis KKG”. Judul ini sudah sangat sesuai dengan situasi dan kondisi yang terjadi pada guru kelas/guru mata pelajaran/bidang studi di SD Negeri 29 Ampenan.

\section{Rumusan Masalah}

"apakah pelaksanaan pendampingan berbasis $\mathrm{KKG}$ dapat meningkatkan kompetensi guru kelas dalam penyusunan soal pilihan ganda semester dua Tahun Pelajaran 2018/2019 di SD Negeri 29 Ampenan? “

\section{Tujuan Penelitian}

untuk mengetahui efektifitas pelaksanaan pendampingan berbasis $\mathrm{KKG}$ upaya meningkatkan kompetensi guru kelas dalam penyusunan soal pilihan ganda semester dua Tahun Pelajaran 2018/2019 di SD Negeri 29 Ampenan.

\section{Manfaat Penelitian}

a. Bagi kepala sekolah : Penelitian ini sangat bermanfaat dalam rangka melaksanakan pendampingan bagi guru kelas di SD Negeri 29 Ampenan dalam penyusunan soal bentuk pilihan ganda yang baik dan benar.

b. Bagi guru kelas : Penelitian ini sangat bermanfaat upaya meningkatkan kompetensi dalam penyusunan soal bentuk pilihan ganda yang baik dan benar, sehingga diharapakan menjadi guru yang profesional dibidangnya masing-masing sesuai dengan kelas yang diampunya.

\section{KAJIAN PUSTAKA \\ Kompetensi Guru.}

Kompetensi adalah seperangkat pengetahuan, ketrampilan, dan prilaku yang harus dimiliki, dihayati, dan dikuasi oleh guru dan dosen dalam melaksanakan tujuan keprofesionalan. Guru mempunyai kedudukan sebagai tenaga professional pada jenjang pendidikan dasar, menengah dan jenjang pendidikan anak usia dini pada jalur pendidikan formal yang diangkat sesuai 
dengan peraturan perundang-undangan (UU No. 14 Tahun 2005).

Guru adalah salah satu komponen manusiawi dalam proses belajar mengajar, yang ikut berperan dalam usaha pembentukan sumber daya manusia yang potensial di bidang pembangunan (Sudirman, 1996:123). Oleh karena itu guru yang merupakan salah satu unsur dibidang kependidikan harus mampu berperan aktif dan menempatkan dirinya sebagai tenaga professional dan betulbetul professional sesuai dengan tuntutan masyarakat yang semakin berkembang. Guru yang berdedikasi untuk kepentingan pelajar tentu tidak akan menuruti kecendrungan modalitasnya di dalam mengajar tetapi akan memperhatikan modalitas pelajarannya di dalam belajar ( Suparta-Herry Noer My 2003:168 ). Pendapat ini mengisyaratkan bahwa dalam upaya meningkatkan motivasi dan hasil belajar peserta didik, harus mengidentifikasi karakteristik pendidiknya dalam proses pembelajaran dan dalam menentukan ketuntasan hasil belajar dengan sistem penilaian yang mencerminkan karakteristik peserta didik dan pemberian soal-soal yang berpariasi seperti soal kajian, pilihan ganda, jawab singkat dan penilaian yang bersifat affektif dan psikomotor.

Yang dimaksud dengan kompetensi guru dalam penelitian tindakan sekolah (PTS) ini adalah upaya peningkatan kemampuan Guru kelas dalam penyusunan soal pilihan ganda, khusus Guru kelas di SD Negeri 29 Ampenan yang dilakukan melalui pendampingan berbasis KKG yang dilaksanakan secara klasikal maupun kelompok kecil (individual).

\section{Kisi-Kisi dan Soal Pilihan Ganda}

Kisi-kisi dapat didefinisikan sebagai matrik informasi yang dapat dijadikan pedoman untuk menulis dan merakit soal menjadi tes. Dengan menggunakan kisi-kisi, penulis soal akan dapat menghasilkan soalsoal yang sesuai dengan tujuan tes dan perakit tes akan mudah menyusun perangkat tes. Beberapa paket tes yang memiliki tingkat kesulitan, kedalaman materi, dan cakupan materi sama (paralel) akan mudah dihasilkan hanya dengan satu kisi-kisi yang baik. (Depdiknas, 2007 : 6)
Format kisi-kisi penyusunan soal memuat indentitas kisi-kisis dan matrik spesifikasi rumusan butir soal. Identitas kisikisi minimal memuat nama satuan pendidikan, mata pelajaran/program studi, kurikulum, alokasi waktu, dan jumlah serta bentuk soal, sedangkan matrik spesifikasi setidaknya mencakup kompetensi dasar (KD), materi, kelas/semester, bentuk sola dan nomor soal.

Soal pilihan ganda merupakan bentuk soal yang jawabannya dapat dipilih dari beberapa kemungkinan jawaban yang telah disediakan. Kontruksinya terdiri dari pokok soal dan pilihan jawaban. Pilihan jawaban terdiri dari kunci dan pengecoh. Kunci jawaban harus merupakan jawaban benar atau paling benar sedangkan pengecoh merupakan jawaban tidak benar, namun daya jebaknya harus berfungsi, artinya peserta didik memungkinkan memilihnya jika tidak menguasai materinya.

Kaidah Penyusunan Soal Pilihan Ganda

Dalam menulis soal pilihan ganda harus memperhatikan kaidah-kaidah sebagai berikut:

Materi : 1) Soal harus sesuai dengan indikator, 2) Pilihan jawaban harus homogen dan logis ditinjau dari segi materi, 3) Setiap soal harus mempunyai satu jawaban yang benar atau yang paling benar.

Konstruksi : 1) Pokok soal harus dirumuskan secara jelas dan tegas, 2) Rumusan pokok soal dan pilihan jawaban harus merupakan pernyataan yang diperlukan saja, 3) Pokok soal jangan memberi petunjuk kearah jawaban benar, 4) Pokok soal jangan mengandung pernyataan yang bersifat negatif ganda, 5) Panjang rumusan pilihan jawaban harus relatif sama, 6) Pilihan jawaban jangan mengandung pernyataan, "semua pilihan jawaban siatas salah", atau "semua pilihann jawaban diatas benar", 7) Pilihan jawaban yang berbentuk angka atau waktu harus disusun berdasarkan urutan besar kecilnya nilai angka tersebut, atau kronologinya, 8) Gambar, grafik, tabel, diagram, dan sejenisnya yang terdapat pada soal harus jelas dan berfungsi, 9) Butir soal jangan bergantung pada jawaban soal sebelumnya. 
Bahasa : 1) Setiap soal harus menggunakan bahasa yang sesuai dengan kaidah Bahasa Indonesia, 2) Jangan menggunakan bahasa yang berlaku setempat, jika soal digunakan untuk daerah lain atau nasional, 3) Setiap soal harus menggunakan bahasa yang komunikatif, 4) Pilihan jawaban jangan mengulang kata atau frase yang bukan merupakan satu kesatuan pengertian.

\section{Pendampingan Klasikal}

Dalam kamus besar bahasa Indonesia pendampingan/bimbingan artinya memberikan petunjuk/penjelasan cara mengerjakan sesuatu, sedangkan kelompok artinya kumpulan (tentang orang, binatang dll). Pendapat lain mengatakan bahwa pendampingan klasikal merupakan salah satu usaha pemberian bantuan kepada orang-orang yang mengalami masalah (Hartinah, 2009 : 12). Sedangkan kelompok adalah untuk melangsungkan hidupnya karena dengan kelompok manusia dapat memenuhi kebutuhan, mengembangkan diri, mengembangkan potensi serta aktualisasi dri (Yusuf, 1998 : 69 dalam Hartinah, 2009 : 20).

Pendampingan klasikal dalam penelitian tindakan sekolah (PTS) ini adalah memberikan petunjuk dan arahan kepada 6 (enam) orang Guru kelas di SD Negeri 29 Ampenan dalam penyusunan soal pilihan ganda sesuai dengan kaidah penyusunan soal pilihan ganda yang baik dan benar.

\section{Pendampingan Individual}

Pendampingan individual artinya seorang pembimbing menghadapi seorang klien (si terbimbing). Mereka berdiskusi untuk pengembangan diri klien, kemudian merencanakan upaya-upaya bagi diri klien yang terbaik baginya (Sofyan S, 2007 : 15). Ini mengisyaratkan bahwa pelaksanaan pendampingan secara individual/perorangan dilaksanakan dalam bentuk diskusi terhadap permasalahan-permasalahan yang hendak dipecahkan oleh seseorang selanjutnya merencanakan tindakan yang tepat dalam upaya pemecahan permasalahan yang dihadapinya.

Dalam penelitian tindakan sekolah (PTS) ini yang dimaksud dengan pendampingan individual adalah seorang Kepala Sekolah memberikan arahan, petunjuk dan trik-trik-trik yang tepat kepada 6 (enam) orang Guru kelas di SD Negeri 29 Ampenan dalam upaya meningkatkan kompetensinya dalam pembuatan kisi-kisi dan penyusunan soal pilihan ganda yang baik dan benar sesuai dengan kaidah penyusunan soal pilihan ganda. Produktifitas individu dapat dinilai dari apa yang dilakukan oleh individu tersebut dalam kerjanya, yakni bagaimana ia melakukan pekerjaan atau unjuk kerjanya (Mulyasa, 2006 : 74). Dalam penelitian ini yang dimaksud dengan unjuk kerja adalah 6 (enam) Guru kelas dalam penyusunan soal pilihan ganda yang dilakukan secara individu dan terbimbing oleh Kepala Sekolah selaku peneliti. Produknya berupa kartu soal pilihan ganda yang sudah diisi dengan baik dan benar sesuai kaidah penyusunan soal pilihan ganda.

\section{Pemahaman Konsep Berfikir Tingkat Tinggi}

Berfikir tingkat tinggi merupakan kemampuan berfikir yang tidak sekedar mengingat (recall), menyatakan kembali (restate), atau merujuk tanpa melakukan pengolahan (recite). Berfikir dalam hal ini meliputi: menemukan, menganalisis, mencipta, merefleksi, dan berargumen. Berfikir tingkat tinggi:

- Critical thinking \& Problem Solving Ketrampilan yang sangat esensial pada abad ke-21

- Critical thinking dapat dilatih berbasis pembelajaran di kelas

- Critical problem solving mencakup:

- Menganalisis situasi yang tidak familiar

- Mengevaluasi strategi pemecahan masalah

- Menciptakan metode baru pemecahan masalah

Difficulity is NOT same as HOT : mengetahui dari arti kata yang jarang digunakan mungkin sulit tetapi ini bukannya HOT kecuali melibatkan proses bernalar (seperti mencari arti kata konteks/stimulus).

\section{Hipotesis Penelitian.}

Pelaksanaan pendampingan klasikal dan kelompok dapat meningkatkan kompetensi Guru kelas di SD Negeri 29 Ampenan dalam penyusunan soal pilihan ganda yang baik dan benar ". 


\section{PROSEDUR PENELITIAN}

\section{Jenis Tindakan}

Penelitian Tindakan Sekolah (PTS) ini dilaksanakan di SD Negeri 29 Ampenan, dengan jumlah peserta 6 (enam) orang Guru kelas yang merupakan tanggung jawab Kepala Sekolah selaku peneliti.

\section{Perencanaan Tindakan}

\section{Jenis tindakan yang dilakukan}

1. Menyampaikan materi yang berkaitan dengan penyusunan soal pilihan ganda yang diawali dengan pembuatan kisi-kisi soal. Untuk kisi-kisi soal komponennya terdiri atas : 1) identitas, 2) Standar kompetensi, 3) Kompetensi Dasar, 4) Kelas/Semester, 5) materi pokok, 6) nomor soal, 7) Rumusan soal, sedangkan kartu soal pilihan ganda komponennya terdiri atas : 1) identitas, 2) Kompetensi Dasar, 3) Materi, 4) Indikator, 5) buku sumber, 6) nomor soal, 7) rumusan butir soal, dan ke 8) kunci jawaban.

2. Skenario pelaksanaannya.

Dalam Penelitian Tindakan Sekolah (PTS) ini, langkah yang akan diambil adalah melalui siklus. Masing-masing siklus menggambarkan proses pendampingan penyusunan soal pilihan ganda yang diawali dengan pembuatan kisi-kisi soal, sesuai dengan proses pendampingan klasikal dan individual. Adapaun skenario pelaksanaan tindakan dapat digambarkan sebagai berikut:

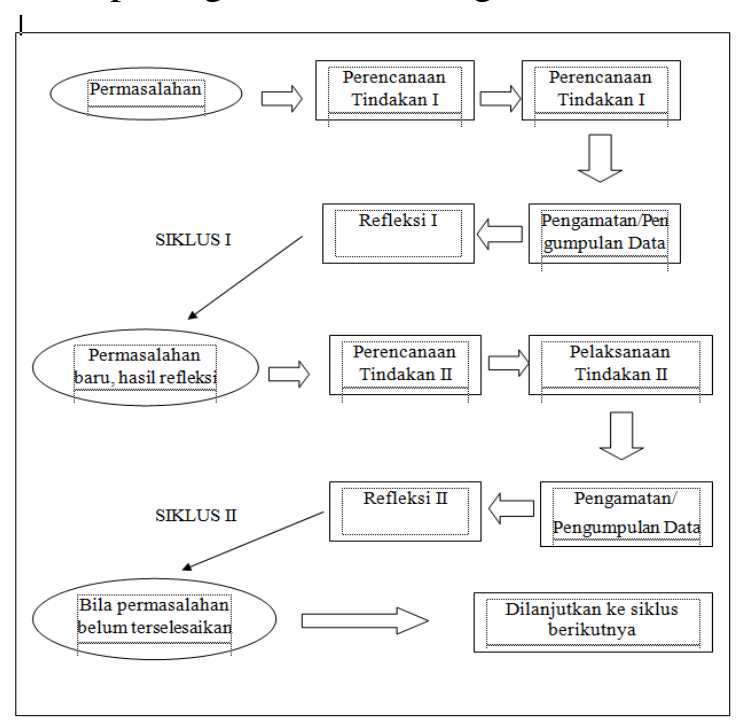

Pelaksanaan Tindakan

Pelaksanaan tindakan yang meliputi diskripsi tindakan yang akan dilakukan meliputi pelaksanaan rencana tindakan yang telah disiapkan, termasuk didalamnya langkah-langkah pelaksanaan atau praktik kekepala sekolahan di sekolah dalam setiap siklus (Suhanjono, 2009:31). Dalam penelitian ini peneliti melakukan pendampingan penyusunan soal pilihan ganda yang diarahkan dengan penyusunan kisi-kisi soal bagi semua Guru kelas di SD Negeri 29 Ampenan dengan berpedoman dengan perencanaan yang telah ditetapkan selama proses tindakan disiapkan instrument sebagai berikut : 1) Instrumen observasi Kepala Sekolah yang akan diisi oleh kepala sekolah selaku observers, 2) Instrument observasi guru peserta pendampingan yang akan diisi oleh Kepala Sekolah selaku peneliti sekaligus pembimbing dalam penyusunan soal pilihan ganda, 3) Instrument penilaian hasil karya guru dalam penyusunan soal pilihan ganda sesuai dengan kaidah penyusunan soal pilihan ganda yang baik dan benar yang akan diisi oleh Kepala Sekolah selaku peneliti.

\section{Evaluasi Dan Refleksi Tindakan}

Tahapan ini adalah melakukan kajian dan penilaian proses tindakan dan hasil atau dampak tindakan terhadap perubahan perilaku sasaran (Nana Sudjana, 2009:39). Kegiatan nyatanya adalah; a) membandingkan hasil pengamatan pelaksanaan diskusi yang terfokus pada penyusunan soal pilihan ganda dengan didahului melakukan penyusunan kisi-kisi soal, b) membandingkan hasil kerja individual dengan indikator keberhasilan yang telah ditetapkan.

Siklus Tindakan.

Penelitian Tindakan Sekolah (PTS) ini direncanakan dilaksanakan sebanyak 2 (dua) siklus, masing-masing siklus 1 (satu) kali pertemuan. Dalam tahapan ini masing-masing siklus kegiatannya terdiri/berisi tentang; 1) perencanaan tindakan, 2) pelaksanaan tindakan, 3) pengamatan/observasi, dan 4) refleksi. Untuk mendapatkan gambaran rinci kegiatan masing-masing siklus dipaparkan sebagai berikut:

\section{SIKLUS I}

\section{Tahap I : Perencanaan Tindakan}

1.1. Menyusun materi pendampingan

1.2. Menetapkan scenario dan langkahlangkah pendampingan yang tertuang 
dalam Rencana Pelaksanaan Pendampingan (RPP)

1.3. Menyusun instrument observasi Kepala Sekolah dan observasi guru

1.4. Menentukan jadwal kegiatan pendampingan

1.5. Menyusun pedoman analisa data hasil observasi dan tugas individu.

Tahap II. Pelaksanaan Tindakan

Tahap I :

Peneliti mengadakan pendampingan

secara berkelompok yang kegiatannya adalah

:

2.1. Menyampaikan materi tentang kaidahkaidah penyusunan soal pilihan ganda yang diawali dengan penyusunan kisikisi soal.

2.2. Melaksanakan diskusi kelompok hasil penyusunan kisi-kisi dan soal pilihan ganda.

2.3. Memberikan bimbingan secara berkelompok/perorangan.

2.4. Memberikan solusi terhadap permasalahan yang dihadapi oleh guru

2.5. Memberikan penguatan/reward

2.6. Memberikan tugas individual.

Tahap II

Peneliti melakukan pendampingan secara individual yang dilakukan secara bergiliran, dengan cara peneliti mendatangi guru pada saat kerja dalam kelompok kecil dalam penyusunan soal pilihan ganda.

Tahap III. Pengamatan/pengumpulan Data

1.1. Pengamatan terhadap aktifitas guru peserta pendampingan

1.2. Pengamatan terhadap kinerja guru dalam penyusunan soal pilihan ganda.

1.3. Menilai hasil kerja guru secara individual

\section{Tahap IV. Refleksi}

4.1. Renungan atas data hasil observasi dan hasil kerja secara individual.

4.2. Pengolahan data hasil penelitian

4.3. Rencana perbaikan dan penyempurnaan

4.4. Memberikan penguatan atas hasil yang diperolehnya.

4.5. Rencana tindak lanjut.

\section{SIKLUS II}

Jenis kegiatan pada siklus II ini pada dasarnya sama dengan siklus I, bedanya hanya terjadi perbaikan/penyempurnaan dalam pelaksanaannya.

\section{Indikator Keberhasilan}

1. Hasil observasi Kepala Sekolah maupun observasi guru selama proses pendampingan telah memperoleh skor rata-rata $\geq 4,0$ (Kategori baik).

2. Hasil kerja guru secara individual dalam penyusunan soal pilihan ganda > 85\% dari jumlah peserta pendampingan memperoleh nilai rata-rata $\geq 85,00$ (kategori tuntas).

\section{LAPORAN HASIL DAN PEMBAHASAN DESKRIPSI SIKLUS I \\ Perencanaan Tindakan}

Peneliti menyiapkan materi pendampingan dalam bentuk power point yang isinya terfokus pada cara penyusunan kisi-kisi soal dan cara penulisan soal pilihan ganda, kegiatan selanjutnya peneliti menyusun Rencana Pelaksanaan Pendampingan (RPP) dengan skenario pendampingan secara klasikal dan pendampingan secara individual. Jenis instrumen yang dibuat oleh peneliti yaitu instrumen pengamatan untuk kepala sekolah selaku peneliti yang menggambarkan aktivitas peneliti selama melakukan proses pendampingan klasikal dan individual. Sedangkan instrument pengamatan untuk peserta (guru) di fokuskan pada aktivitas selama melakukan kerjasama/diskusi kelompok dengan sesama anggota kelompok maupun antar anggota kelompok lain.

\section{Pelaksanaan Tindakan}

Peneliti mengumpulkan 6 (enam) guru kelas tinggi SD Negeri 26 Ampenan dari pukul 09.00 - 13.00 wita. Pada pertemuan klasikal ini peneliti menyampaikan materi pendampingan dengan berbagai strategi dan metode terkait dengan penyusunan kisi-kisi dan tata cara penulisan soal pilihan ganda dengan berpedoman pada kaidah penulisan soal pilihan ganda yang baik dan benar.

Kegiatan dilanjutkan dengan pelaksanaan diskusi kelompok/kerja kelompok untuk menyusun kisi-kisi soal. Peserta dibagi menjadi 2 (dua) kelompok kecil, masing-masing kelompok beranggotakan 3 (tiga) orang. Kelompok I membuat kisi-kisi dan soal pilihan ganda 
materi kelas rendah (kelas I, II, III), tiap-tiap anggota kelompok membuat 2 (dua) soal sesuai dengan 16 (enam belas) aspek sesuai dengan kaidah penulisan soal pilihan ganda yang baik dan benar. Kelompok II membuat kisi-kisi dan soal materi kelas tinggi (Kelas IV, V, VI).

\section{Pengamatan/Pengumpulan Data}

Hasil observasi kepala sekolah/peneliti yang dilakukan oleh pengawas pembimbing di peroleh skor rata-rata sebesar 3,50, hasil Observasi Guru selama proses diskusi kelompok dalam penyusunan kisi-kisi soal pilihan ganda diperoleh skor rata-rata sebesar 3,60, hasil kerja individual dalam penulisan soal pilihan ganda memperoleh nilai rata-rata sebesar 77,81.

\section{Refleksi}

Peneliti merenung atas data hasil observasi maupun data hasil kerja secara individual dalam penulisan soal pilihan ganda. Pada kegiatan pengamatan guru selama proses pendampingan klasikal maupun individual tidak ada guru yang dinyatakan tuntas Selebihnya masih dibawah rata-rata yang diharapkan. Begitu juga dalam perolehan nilai rata-rata hasil kerja individual tidak ada yang memenuhi indikator keberhasilan, selebihnya masih di bawah indikator keberhasilan yaitu $\geq 85,00$ (kategori baik)

\section{DESKRIPSI SIKLUS II}

\section{Perencanaan tindakan}

Pada kesempatan ini peneliti menyiapkan materi pendampingan yang lebih difokuskan pada kegiatan remidi/perbaikan terhadap hasil perolehan pada siklus I, dilanjutkan dengan penajaman materi tentang kaidah penulisan soal pilihan ganda yang dijelaskan secara rinci disertai dengan pemberian contoh konkrit soal pilihan ganda yang memenuhi syarat sesuai dengan 16 (enam belas) butir kaidah penulisan soal yang baik dan benar. Selanjutnya peneliti membuat skenario pelaksanaan diskusi kelompok dan presentasi hasil kerja kelompok.

\section{Pelaksanaan tindakan}

Pelaksanaan tindakan pada siklus II ini tetap dipusatkan di SD Negeri 29 Ampenan pada hari Senin tanggal 11 Februari 2019 dari pukul 09.00 - 13.00 wita dengan urutan kegiatan sebagai berikut : 1) peneliti mengklarifikasi hasil kerja individual pada siklus I sekaligus diadakan perbaikan dan penyempurnaan sebagaimana yang telah dicantumkan dalam penulisan soal pilihan ganda sesuai kaidah yang baik dan benar, 2) kegiatan dilanjutkan dengan pemberian tugas yang harus dikerjakan secara individual tetapi pelaksanaannya didiskusikan dengan teman sekelompoknya dibawah pendampingan kepala sekolah selaku peneliti, 3) pada saat peserta bekerjasama dalam kelompok peneliti berkeliling mengadakan pengamatan dan pendampingan secara bergiliran, 4) selama proses pendampingan peneliti memberikan penguatan kepada semua guru baik yang mampu mengerjakan tugas dengan cepat dan tepat maupun guru yang mengerjakan tugas agak lamban dan perlu pendampingan khusus, 5) pada akhir pendampingan peneliti mempersilahkan masing-masing kelompok untuk mempersentasikan hasil kerjanya dihadapan peserta secara bergiliran sampai ke 2 kelompok semua tampil mempersentasikan hasil kerjanya.

\section{Pengamatan/pengumpulan data}

Hasil observasi kepala sekolah/peneliti yang dilakukan oleh pengawas pembimbing di peroleh skor rata-rata sebesar 4,50, hasil Observasi Guru selama proses diskusi kelompok dalam penyusunan kisi-kisi soal pilihan ganda diperoleh skor rata-rata sebesar 4,37, hasil kerja individual dalam penulisan soal pilihan ganda memperoleh nilai rata-rata sebesar 92,24.

\section{Refleksi}

Hasil renungan terhadap perolehan skor dalam pengamatan maupun perolehan nilai hasil kerja individual dalam penulisan soal pilihan ganda pada siklus II ini mengalami peningkatan yang tajam dan sangat signifikan. Pada semua data dari instrumen observasi kepala sekolah maupun observasi guru mengalami peningkatan., hal ini disebabkan karena kesalahan-kesalahan yang terjadi pada siklus I telah diminimalkan terutama pada pelaksanaan pendampingan secara klasikal maupun pendampingan secara individual.

Karena indikator keberhasilan telah tercapai maka Penelitian Tindakan Sekolah 
(PTS) dihentikan pada siklus II dengan hasil sangat memuaskan. Selanjutnya peneliti segera membuat draf penyusunan laporan terhadap apa yang telah dilakukan selama penelitian dari kegiatan perencanaan sampai hasil akhir dari seluruh kegiatan penelitian ini. Secara rinci, sederhana, dan mudah difahami oleh semua pihak yang berkepentingan dengan penelitian ini.

\section{Pembahasan \\ SIKLUS I}

\section{Perencanaan tindakan}

Pada tahapan ini, ada beberapa kendala yang dihadapi diantaranya adalah dalam menyiapkan semua materi yang berhubungan dengan pendampingan penulisan soal pilihan ganda, Rencana Pelaksanaan Pendampingan (RPP) tentang scenario pendampingan penulisan soal pilihan ganda, dan penyusunan instrument observasi kepala sekolah dan observasi guru. Tetapi setelah berkonsultasi dan meminta petunjuk kepada pembimbing, kendala yang dihadapi dapat diatasi dengan baik.

\section{Pelaksanaan Tindakan}

Pada pelaksanaan pendampingan secara klasikal dan individual yang dimulai pukul 09.00 sampai pukul 13.00 wita terpusat di SD Negeri 29 Ampenan bisa berjalan tetapi tidak sesuai dengan waktu yang telah direncanakan, penyebabnya adalah ketika pendampingan dimulai tepat pukul 09.00 masih ada peserta yang belum hadir. Solusinya peneliti terpaksa mengulang materi pendampingan secara sepintas agar peserta yang terlambat hadir mengetahui isi materi pendampingan. Hasilnya semua materi telah disampaikan kepada semua peserta pendampingan.

Pada akhir pendampingan peneliti memberikan tugas secara individual yaitu menyelesaikan/memperbaiki/penyempurnaan tugas yang dikerjakan dalam kegiatan kerja kelompok. Pada kegiatan ini tidak ada hambatan yang berarti, semua berjalan lancer sehingga tidak perlu ada solusi.

\section{Pengamatan/pengumpulan data}

Hasil observasi kepala sekolah diperoleh skor rata-rata $(3,50)$, sementara indikator kinerja mengharapkan mendapat skor rata-rata $(\geq 4,00)$, sementara perolehan skor rata-rata observasi guru adalah $(3,60)$. Ini artinya belum memenuhi indikator keberhasilan yang diharapkan yaitu $(\geq 4,00)$. Sedangkan hasil kerja secara individual dalam penulisan soal pilihan ganda yang sesuai kaidah penulisan soal pilihan ganda yang baik dan benar di peroleh nilai rata-rata adalah $(77,81)$, sementara indikator keberhasilan proses bimbingan individual dinyatakan telah berhasil jika perolehan nilai rata-rata $(\geq$ 85,00).

\section{Refleksi}

Hasil observasi kepala sekolah memperoleh skor rata-rata $(3,50)$ sementara hasil observasi guru memperoleh skor $(3,60)$ dan hasil nilai rata-rata kerja individual dalam penulisan soal pilihan ganda adalah 77,81. Dari ketiga perolehan data hasil penelitian pada siklus I masih belum memenuhi target indikator keberhasilan yang telah ditetapkan. Jenis tindakan yang akan dilakukan dalam proses pendampingan secara klasikal antara lain: 1) pengamatan yang berkesinambungan, 2) pendampingan secara klinis, 3) pemanfaatan waktu yang efektif. Sedangkan tindakan nyata yang dilakukan oleh peneliti dalam pendampingan individual antara lain: 1) memperbaiki hasil kerja yang masih belum sempurna, 2) berbicara yang santun selama pendampingan, dan 3) memberikan penguatan yang positif dan bersifat membimbing. Tindakan nyata itu perlu dilakukan dalam upaya meningkatkan kompetensi guru kelas tinggi di SD Negeri 29 Ampenan demi terwujudnya system penilaian yang valid dan reliable.

\section{SIKLUS II}

\section{Perencanaan Tindakan}

Tahap awal yang dilakukan oleh peneliti adalah membuat perencanaan refleksi hasil perolehan data pada siklus I yang disampaikan di depan seluruh guru peserta pendampingan. Dalam kegiatan ini peneliti tidak mengalami kendala, semua berjalan lancar. Aspek-aspek yang merupakan kesalahan guru dalam mengerjakan tugas individual diperbaiki dan disempurnakan melalui forum Tanya jawab selama penyampaian materi refleksi.

\section{Pelaksanaan Tindakan}


Dalam pelaksanaan bimbingan secara klasikal maupun individual pada siklus II ini diawali dengan kegiatan refleksi perolehan hasil pada siklus I dilanjutkan dengan penyampaian materi pendampingan dan dilanjutkan dengan diskusi kelompok/kerja kelompok penulisan soal pilihan ganda sesuai dengan kisi-kisi yang telah dibuat terlebih dahulu.

\section{Pengamatan/Pengumpulan Data}

Perolehan hasil observasi kepala sekolah pada siklus II mencapai skor rata-rata $(4,50)$ dari indikator keberhasilan $(\geq 4,00)$, sedangkan hasil observasi guru mencapai skor rata-rata $(4,37)$ dari indikator keberhasilan $(\geq$ $4,00)$ dan hasil nila rata-rata yang dicapai oleh peserta pendampingan penulisan soal pilihan ganda adalah $(92,24)$ dari indicator keberhasilan $(\geq 85,00)$.

\section{Refleksi}

Hasil pengamatan terhadap kepala sekolah selaku peneliti yang dilakukan oleh observer memperoleh skor rata-rata $(4,50)$ dan indikator keberhasilan $\geq 4,00$, sementara hasil pengamatan terhadap efektifitas guru peserta pendampingan pada kegiatan diskusi kelompok diperoleh skor rata-rata $(4,37)$ dari indikator keberhasilan $\geq 4,00$, sedangkan niali rata-rata hasil kerja secara individual dalam penulisan soal pilihan ganda adalah $(92,24)$ dari indikator keberhasilan $\geq 85,00$.

Penelitian Tindakan Sekolah (PTS) diakhiri pada siklus II sesuai dengan rencana yang telah di terangkan pada proposal. Halhal yang mengandung nilai positif dan mampu meningkatkan kompetensi guru kelas tinggi perlu terus dilakukan dalam rangka perwujudan kepala sekolah yang berkualitas dan memiliki kompetensi dalam pengembangan keprofesian berkelanjutan (PKB).

\section{KESIMPULAN}

Kompetensi guru kelas di SD Negeri 29 Ampenan dalam penulisan soal pilihan ganda yang diawali dengan pembuatan kisikisi soal bentuk pilihan ganda dapat ditingkatkan melalui kegiatan pendampingan secara klasikal dan secara individual. Peningkatan kompetensi dimaksud di dukung oleh data hasil penelitian sebagai berikut:

\begin{tabular}{|c|l|c|c|c|c|}
\hline No & \multicolumn{1}{|c|}{ Jenis Kegiatan } & $\begin{array}{c}\text { Indikator } \\
\text { keberhasilan }\end{array}$ & $\begin{array}{c}\text { Siklus } \\
\text { I }\end{array}$ & Siklus II & Keterangan \\
\hline 1. & Observasi Kepala sekolah & $\geq 4,00$ & 3,50 & 4,50 & Tuntas \\
\hline 2. & Observasi Guru & $\geq 4,00$ & 3,60 & 4,37 & Tuntas \\
\hline 3. & Kerja Individual & $\geq 85,00$ & 77,81 & 92,24 & Tuntas \\
\hline
\end{tabular}

Pendampingan klasikal dan pendampingan individual sangat efektif dalam upaya meningkatkan kompetensi guru kelas dalam penulisan soal pilihan ganda, karena didukung oleh data hasil tindakan nyata melalui penelitian tindakan sekolah (PTS). Perkembangan data hasil observasi dari siklus I ke siklus II mengalami peningkatan sehingga indicator keberhasilan dapat terlampaui. Demikian pula perolehan nilai hasil kerja individual pada siklus ke II telah meningkat dan melampaui indikator keberhasilan.

Keberhasilan ini merupakan wujud kerjasama yang baik antara kepala sekolah selaku peneliti dengan 6 (enam) orang guru kelas di SD Negeri 29 Ampenan. Selama satu bulan telah mengadakan pendampingan secara berkesinambungan sehingga nilai tambah dari hasil penelitian ini adalah terciptanya suasana kekeluargaan yang semakin harmonis.

Karena indikator keberhasilan dalam penelitin ini telah tercapai maka penelitian tindakan sekolah (PTS) dengan judul "Meningkatkan Kompetensi Guru SD Negeri 29 Ampenan Semester Dua Tahun Pelajaran 2018/2019 Dalam Penulisan Soal Pilihan Ganda Yang Berkriteria Untuk Berfikir Tingkat Tinggi Melalui Pendampingan Berbasis KKG" dinyatakan "BERHASIL", penelitian dihentikan pada siklus II.

\section{SARAN}

Kepala sekolah sejawat, diharapkan untuk mengadakan penelitian yang sama dalam upaya meningkatkan kompetensi guru yang menjadi binaannya terkait dengan tugas dan tanggung jawabnya sebagai guru mata pelajaran. Pelaksanaan penelitian itu diharapkan mengacu pada hasil yang telah diperoleh oleh kepala sekolah SD Negeri 29 Ampenan dalam penulisan soal pilihan ganda sesuai dengan kaidah penulisan soal pilihan ganda yang baik dan benar. Dalam penelitian itu peneliti mengadakan pendampingan secara klasikal maupun secara individual terhadap 6 
(enam) guru kelas di SD Negeri 29 Ampenan..

Kepada guru kelas yang terlibat dalam penelitian ini agar mampu mengaplikaasikan dalam proses pembelajaran di kelas senyatanya dalam bentuk ulangan harian, ujian tengah semester, ujian semester, maupun ujian sekolah. Selain itu diharapkan guru sebagai peserta pendampingan, pasca mengikuti kegiatan mampu menularkan kepada guru mata pelajaran lain tentang tata cara penulisan soal pilihan ganda sesuai dengan kaidah penulisan soal yang baik dan benar, didahului dengan penyusunan kisi-kisi soal pilihan ganda yang baik dan benar.

\section{DAFTAR PUSTAKA}

Arikanto, S, 2006, Penelitian Tindakan Kelas, Jakarta: Bumi Aksara.

Depdiknas, 2007, Panduan Penulisan Soal Pilihan Ganda, Jakarta: Pusat Penilaian Pendidikan Balitbang.

Depdiknas, 2001, Kamus Besar Bahasa Indonesia, Jakarta: Balai Pustaka.

Hartinah, S, 2009, Konsep Dasar Bimbingan Kelompok, Bandung: Pelita Aditama.

Kementrian Nasional, 2011, Pedoman Kegiatan, Pengembangan Keprofesian Berkelanjutan (PKB), Jakarta: Direktorat Pembinaan Pendidik dan Tenaga Kependidikan Pendidikan Dasar.

Kementrian Nasional, 2011, Buku Kerja Kepala sekolah Sekolah, Jakarta: Pusat Pengembangan Tenaga Kependidikan Badan Pengembangan Sumber Daya Manusia Pendidikan Dan Penjamin Mutu Pendidikan.

Kementrian Pendidikan Dan Kebudayaan, 2016, Panduan Bagaimana Pendidik Dapat Menulis Soal Yang Berkriteria Untuk Berfikir Tinggi, Jakarta: Direktorat Pembinaan Sekolah Dasar.

Nana Sudjana, 2009, Penelitian Tindakan Kekepala sekolahan Konsep Dan Aplikasinya Bagi Kepala sekolah Sekolah, Jakarta: LPP Bina Mitra.

Radno Harsanito, 2007, Pengelolaan Kelas Yang Dinamis, Paradigma Baru Pembelajaran Menuju Kompetensi Siswa, Yogyakarta: Kanisius.
Suhardjono, 2006, Penelitian Tindakan Kelas Sebagai Kegiatan Pengembangan Profesi Guru, Jakarta: Bumi Aksara.

Suhardjono, 2009, Melaksanakan Sekolah Sebagai Kegiatan Penelitian Tindakan Sekolah Sebagai Kegiatan Pengembangan Profesi Kepala sekolah Sekolah, Jakarta: Bumi Aksara.

Suhardjono, dkk, 2012, Publikasi Ilmiah Dalam Kegiatan Pengembangan Keprofesian Berkelanjutan Bagi Guru, Jakarta: Cakrawala Indonesia.

Sardiman, 1996, Interaksi Dan Motivasi Belajar Mengajar Pedoman Bagi Guru Dan Calon Guru, Jakarta: Ocafindo.

Suparta-Harry Noer Aly, 2003, Metodologi Pengajaran Agama Islam, Jakarta: Amisscd.

Sofyans, 2007, Konseling Individual Teori Dan Praktik, Bandung: Alfabeta.

Undang-undang Nomor 11 Tahun 2005 Tentang Guru Dan Dosen.

User Usman, 2001, Menjadi Guru Profesional, Bandung: Remaja Rosda Karya.

Wiriatmadja, 2007, Metode Penelitian Tindakan Sekolah Sebagai Karya Tulis Ilmiah Dalam Kegiatan Pengembangan Profesi Kepala sekolah Sekolah, Jakarta: Dirjen PMPTK

Zainal Arifin, 2013, Evaluasi Pembelajaran, Bandung: PT Remaja Rosdakarya 